\title{
The analysis of human papillomavirus DNA in penile cancer tissue by in situ hybridization
}

\author{
DAIJI TAKAMOTO ${ }^{1}$, TAKASHI KAWAHARA ${ }^{1,2}$, JUN KASUGA ${ }^{1}$, TAKESHI SASAKI ${ }^{3}$, \\ MASAHIRO YAO $^{2}$, YASUSHI YUMURA ${ }^{1}$ and HIROJI UEMURA ${ }^{1}$ \\ ${ }^{1}$ Department of Urology and Renal Transplantation, Yokohama City University Medical Center, Yokohama, \\ Kanagawa 2360004; ${ }^{2}$ Department of Urology, Yokohama City University Graduate School of Medicine, \\ Yokohama, Kanagawa 2320024; ${ }^{3}$ Department of Hospital Coordinate Promotion and Telepathology, \\ Tokyo University Hospital, Tokyo 1138655, Japan
}

Received August 24, 2017; Accepted January 11, 2018

DOI: $10.3892 / \mathrm{ol} .2018 .8351$

\begin{abstract}
Primary penile cancer is a rare disease. Higher incidence rates occur in underdeveloped countries. Many studies have suggested an association between human papillomavirus (HPV) infection and penile cancer. Although HPV can affect the squamous epithelium of the male genitalia similarly to the female genital tract, the association between penile cancer and HPV remains unclear. In the present study, the HPV gene expression was examined in penile cancer tissue using in situ hybridization (ISH). The present study included 41 cases in which penectomy was performed and 3 cases in which tumor resection was performed to treat pathologically-diagnosed penile cancer at Yokohama City University Medical Center, and its 7 affiliated hospitals between April 1990 and March 2010. The penile cancer tissue was subjected to an ISH analysis, and the clinicopathological features and prognosis were investigated. A total of 5/44 cases (11.4\%) showed the expression of high-risk HPV. None of the patients showed the expression of low-risk HPV. The associations between the expression of high-risk HPV, and age, tumor location, tumor size, $\mathrm{T}$ stage, pathological differentiation, nuclear grade, Broder's classification, pattern of invasion, Y-K grade, vascular invasion, lymphoid invasion, koilocytosis and lymph-node metastasis were then examined. Patients with a well-differentiated status $(\mathrm{P}=0.044)$ and Broder's Grade $1(\mathrm{P}=0.019)$ showed a significantly lower rate of HPV positivity. The HPV expression was not significantly associated with cancer specific survival $(\mathrm{P}=0.932)$. ISH using INFORM HPV III does not detect the HPV genotype, this method is easy to employ and may be
\end{abstract}

Correspondence to: Dr Takashi Kawahara, Department of Urology and Renal Transplantation, Yokohama City University Medical Center, 4-57 Urafune-cho, Minami-ku, Yokohama, Kanagawa 2360004, Japan

E-mail: takashi_tk2001@yahoo.co.jp

Key words: penile cancer, in situ hybridization, human papillomavirus useful for the diagnosis of penile cancer tissue, similarly to cervical cancer.

\section{Introduction}

Primary penile cancer is a rare disease. The incidence of penile cancer is heterogeneous among different populations; however, it is rare in most of the developed world. In the United States, the age-standardized incidence is $0.3-1.8 / 100,000$ population $(1,2)$. The incidence of penile cancer is high in developing countries, including Uganda $(2.8 / 100,000)$, and areas of Brazil $(1.5-3.7 / 100,000)$. The reasons for this are thought to be as follows: i) A high risk of HPV infection; ii) sufficient medical aid not performed; and iii) a high smoking rate (3). Israeli Jews show the lowest incidence in the world $(0.1 / 100,000)$. The incidence of penile cancer in Japan is approximately $0.4 / 100,000$; this rate is similar to the rates in other developed countries (4).

Previous studies have suggested that human papillomavirus (HPV) infection is associated with penile cancer (5-7). Oncogenic HPV infection has been well established as a major risk factor for cervical cancer and is associated with the development of $>99 \%$ of cervical carcinomas. Although it is known that HPV can affect the squamous epithelium of the male genitalia (similarly to the female genital tract) the association between penile cancer and HPV has not been completely elucidated.

Cancer tissue specimens have recently been investigated using HPV DNA assays, including polymerase chain reactions (PCRs) and in situ hybridization (ISH). Although PCRs show high sensitivity in the detection of HPV DNA, there are some disadvantages associated with using PCRs to detect HPV DNA $(8,9)$, as the assay requires highly trained laboratory personnel and strict laboratory conditions must be implemented to avoid contamination. Moreover, the morphological context is lost when a PCR is used.

In contrast, ISH works by directly detecting the signals of HPV DNA and the morphological context is preserved. The results of ISH are interpreted similarly to the results of immunohistochemical staining. ISH signal patterns of HPV DNA have been reported to be some correlation with the physical status of HPV in infected cells (10). The integration 
of oncogenic HPV into the human genome is a crucial stage of cervical cancer carcinogenesis; thus, the HPV signal pattern, which possibly suggests the viral integration status, may be a useful marker that can be used to predict the progression of precancerous lesions. In spite of these advantages, ISH shows low sensitivity. For pathologists who use ISH to detect HPV in tissue, this is a major concern (11). ISH assays using improved signal-detecting methods, which show higher sensitivity, including the enzyme-categorized signal detecting system, have been developed in recent years (12).

The majority of cervical cancers ( $>90 \%)$ express HPV and the HPV vaccine has an important role to play in preventing cervical. In the present study, we performed ISH to examine the HPV gene expression in penile cancer tissue.

\section{Patients and methods}

The study population. Forty-one cases involving patients who underwent penectomy and 3 cases involving patients who underwent tumor resection to treat pathologically-diagnosed penile cancer were included in the present study. All of the patients were treated at Yokohama City University Medical Center (Yokohama, Japan) and its 7 affiliated hospitals between April 1990 and March 2010. The primary tumor was removed by amputation or tumor resection. Ethical approval and consent to participate: The present study was approved by the Institutional Review Board of Yokohama City University and written informed consent was obtained from the patients.

Histopathological features. One pathologist (T.S.) performed a histological review) using 3.5- $\mu$ m-thick tissue sections that had been stained with hematoxylin and eosin (Fig. 1). The following pathological variables were investigated: The depth of tumor invasion, the grade of histological differentiation, the grade of infiltration, Broder's grade Yamamoto-Kohama (Y-K) grade, and the presence/absence of lymphovascular embolization and koilocytosis.

ISH. ISH was performed using tissue specimens (thickness, $4-\mu \mathrm{m}$ ) that had been obtained during penectomy. The sections were subjected to ISH studies with Ventana HPV III probes (Ventana Medical Systems, Inc., Tucson, AZ, USA). The Ventana INFORM HPV assay is able to detect both high-risk (HR) HPV $(16,18,31,33,35,45,51,55,58,59,68$, and 70) and low-risk (LR) HPV $(6,11,42-44)$ types, just as with cervical cancer (13). A sandwich hybridization reaction that consists of a fluorescein-labeled probe that is complimentary to the HPV target, a primary biotinylated linking antibody (anti-FIC, as well as antibiotin or antidigoxigenin), a secondary biotinylated linking antibody, and an alkaline phosphatase conjugated avidin, stains cells that are positive for HPV DNA with a blue color (Figs. 2 and 3). An ISH iVIEW Blue BPlus Detection kit is used to detect the labeling (Ventana Medical Systems, Inc.) (8). The staining runs each included appropriate positive and negative controls (provided by the manufacturer).

Follow-up procedures. The follow-up procedures included a physical examination every three months during the first 2 years, every 6 months in the third year and annually from the fourth year. Computed tomography was performed every 6 months.

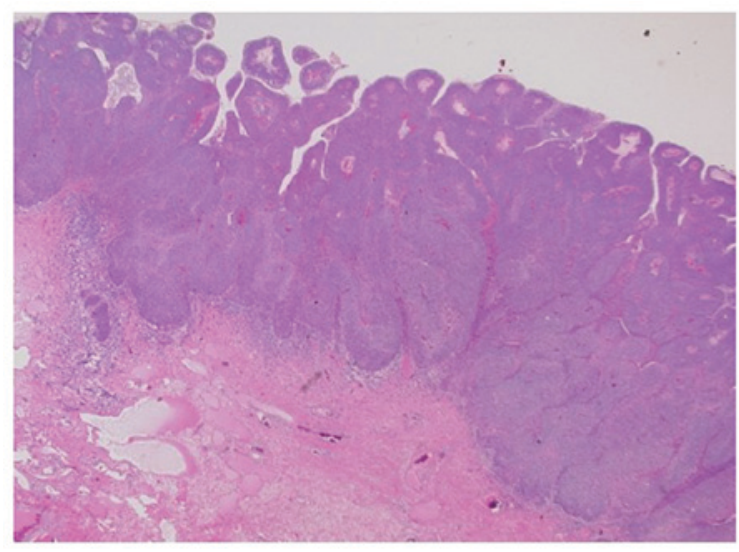

Figure 1. Hematoxylin and eosin staining (magnification, x12.5).

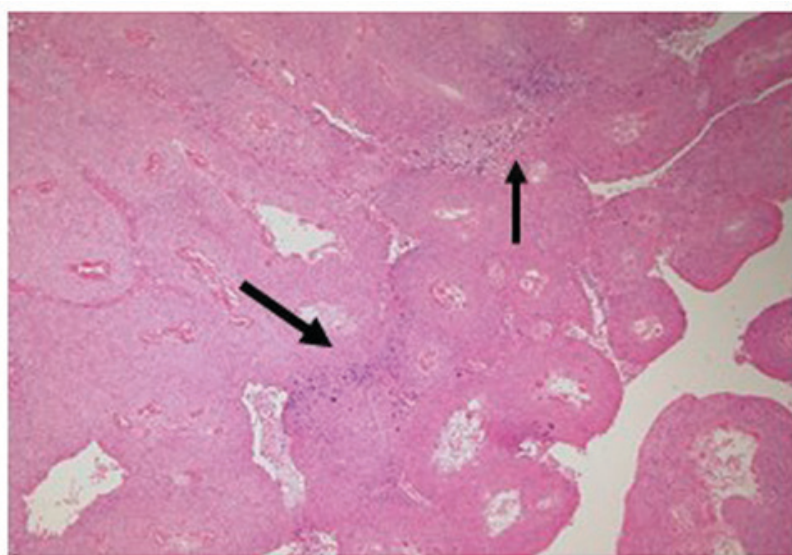

Figure 2. HPV HR ISH (magnification, x40). HPV infected cells are shown in blue (black arrows). HPV, human papillomavirus; HR, high-risk; ISH, in situ hybridization.

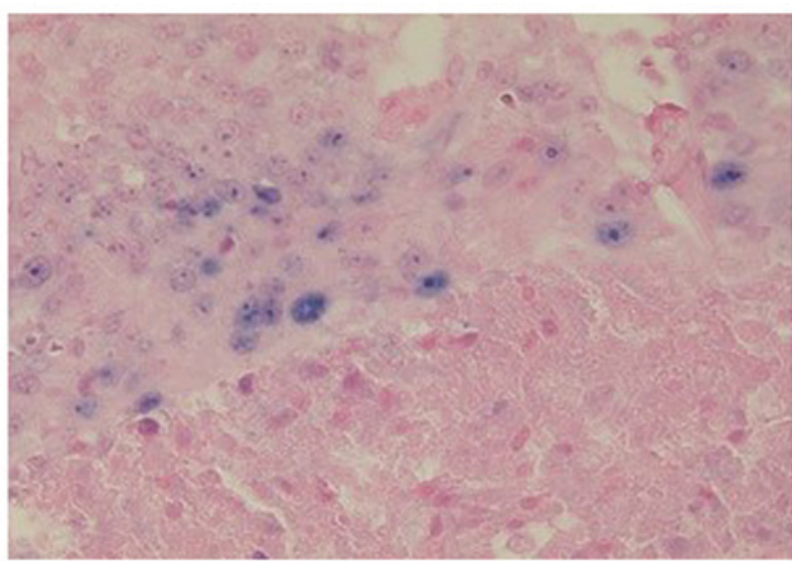

Figure 3. HPV HR ISH (magnification, x400). HPV, human papillomavirus; HR, high-risk; ISH, in situ hybridization.

Statistical analysis. The Mann-Whitney U and chi-squared tests were performed to analyze the patients' characteristics and preoperative factors. Multivariate logistic regression analyses were used to identify individual factors. The Kaplan-Meier product limit estimator was used for the estimation of OS. The survival duration (defined as the time between radical 
Table I. Clinicopathological features.

\begin{tabular}{|c|c|c|c|c|}
\hline \multirow[b]{2}{*}{ Variable } & \multirow[b]{2}{*}{ Total } & \multicolumn{2}{|c|}{ HR HPV } & \multirow[b]{2}{*}{ P-value } \\
\hline & & Positive (n=5) & Negative $(\mathrm{n}=39)$ & \\
\hline Mean age (years) & $68.6 \pm 11.7$ & $72.8 \pm 11.5$ & $68.0 \pm 10.9$ & $0.335^{\mathrm{a}}$ \\
\hline Location & $\begin{array}{c}\text { Glans/foreskin/shaft } \\
32 / 8 / 4\end{array}$ & $\begin{array}{c}\text { Glans/foreskin/shaft } \\
4 / 1 / 0\end{array}$ & $28 / 7 / 4$ & 0.754 \\
\hline Mean size (cm) & $3.5 \pm 2.6$ & $3.44 \pm 1.53$ & $3.77 \pm 2.51$ & $0.912^{\mathrm{a}}$ \\
\hline T stage & $\begin{array}{c}\mathrm{T} 1 / \mathrm{T} 2 / \mathrm{T} 3 / \mathrm{T} 4 \\
\text { 25/12/5/2 }\end{array}$ & $\begin{array}{c}\mathrm{T} 1 / \mathrm{T} 2 / \mathrm{T} 3 / \mathrm{T} 4 \\
2 / 3 / 0 / 0\end{array}$ & $23 / 9 / 5 / 2$ & 0.335 \\
\hline Differentiation & $\begin{array}{c}\text { Well/mod/poor } \\
21 / 17 / 6\end{array}$ & $\begin{array}{c}\text { Well } / \mathrm{mod} / \text { poor } \\
0 / 3 / 2\end{array}$ & $21 / 14 / 4$ & 0.044 \\
\hline Nuclear grade & $\begin{array}{c}\mathrm{G} 1 / \mathrm{G} 2 / \mathrm{G} 3 \\
13 / 22 / 9\end{array}$ & $\begin{array}{c}\mathrm{G} 1 / \mathrm{G} 2 / \mathrm{G} 3 \\
0 / 3 / 2\end{array}$ & $13 / 19 / 7$ & 0.243 \\
\hline Broders & $\begin{array}{c}\mathrm{G} 1 / \mathrm{G} 2 / \mathrm{G} 3 / \mathrm{G} 4 \\
17 / 10 / 9 / 8\end{array}$ & $\begin{array}{c}\mathrm{G} 1 / \mathrm{G} 2 / \mathrm{G} 3 / \mathrm{G} 4 \\
0 / 0 / 2 / 3\end{array}$ & $17 / 10 / 7 / 5$ & 0.019 \\
\hline Infiltration grade & $\begin{array}{c}\alpha / \beta / \gamma \\
8 / 32 / 4\end{array}$ & $\begin{array}{l}\alpha / \beta / \gamma \\
0 / 4 / 1\end{array}$ & $8 / 28 / 3$ & 0.406 \\
\hline Y-K grade & $\begin{array}{c}\mathrm{G} 1 / \mathrm{G} 2 / \mathrm{G} 3 / \mathrm{G} 4 \\
1 / 17 / 17 / 9\end{array}$ & $\begin{array}{c}\mathrm{G} 1 / \mathrm{G} 2 / \mathrm{G} 3 / \mathrm{G} 4 \\
0 / 1 / 1 / 3\end{array}$ & $1 / 16 / 16 / 6$ & 0.141 \\
\hline Vascular invasion & $\begin{array}{l}\text { Yes/no } \\
11 / 33\end{array}$ & $\begin{array}{c}\text { Yes/no } \\
3 / 2\end{array}$ & $8 / 31$ & 0.055 \\
\hline Lymph node invasion & $\begin{array}{l}\text { Yes/no } \\
4 / 40\end{array}$ & $\begin{array}{c}\text { Yes/no } \\
1 / 4\end{array}$ & $3 / 36$ & 0.367 \\
\hline Koilocytosis & $\begin{array}{l}\text { Yes/no } \\
18 / 26\end{array}$ & $\begin{array}{l}\text { Yes/no } \\
2 / 3\end{array}$ & $16 / 23$ & 0.965 \\
\hline N stage & $\begin{array}{l}0 / 1 / 2 / 3 \\
34 / 1 / 5 / 4\end{array}$ & $\begin{array}{l}0 / 1 / 2 / 3 \\
3 / 0 / 2 / 0\end{array}$ & $31 / 1 / 3 / 4$ & 0.177 \\
\hline
\end{tabular}

${ }^{a}$ Mann-Whitney U test. The others are Chi-square test. HPV, human papillomavirus; HR, high-risk; Y-K, Yamamoto-Kohama grade; T stage, tumor stage; N stage, node stage.

cystectomy and death) was compared using a log-rank test. $\mathrm{P}<0.05$ was considered to indicate a statistically significant difference.

\section{Results}

Patients' characteristics. A total of 44 patients with penile cancer who underwent penectomy were included in the present study. The mean (median) age was 68.6 \pm 11.7 (69) years. The locations of the cancerous lesions in these patients included the glans $[\mathrm{n}=32(72.7 \%)]$, the foreskin $[\mathrm{n}=8(18.2 \%)]$, and the body [n=4 (9.1\%)]. The UICC stage classifications were as follows: Stage $1[\mathrm{n}=24(54.5 \%)]$, stage $2[\mathrm{n}=10(22.7 \%)]$, stage $3[\mathrm{n}=4$ $(9.1 \%)]$, and stage 4 [n=6 (13.6\%)]. Most of the patients were usual type, and three patients were verrucus type. None showed basaloid or warty types. The mean tumor size was $3.5 \pm 2.6 \mathrm{~cm}$ (median $3.7 \mathrm{~cm}$, range $0.25-10 \mathrm{~cm}$ ). The surgical treatments included partial penectomy [ $\mathrm{n}=29$ (65.9\%)], total penectomy $[\mathrm{n}=12(27.3 \%)]$, and tumor resection preserving the penis $[\mathrm{n}=3$ (6.8\%)]. Inguinal canal lymph-node resection was performed in 16 cases $(36.4 \%)$ and receiver intra-pelvic node resection was performed in two cases (4.5\%). Lymph-node resection was not performed in the other 26 cases (59.1\%). Thirteen patients
(29.5\%) received adjuvant chemotherapy. Adjuvant radiation therapy was performed in 6 cases (13.6\%). The mean follow-up period was 44.1 months (median, 23.5). Fifteen cases (34.1\%) showed recurrence or progression. Nine patients $(20.5 \%)$ died due to penile cancer, $8(18.2 \%)$ died due to other reasons, and one patient (2.3\%) survived with recurrent penile cancer; the remaining 26 cases (59.1\%) survived without recurrence. The pathological $\mathrm{T}$ stage, tumor differentiation, nuclear grade, and Broder's classification are summarized in Table I. Eighteen cases $(40.9 \%)$ showed koilocytosis. Preoperative CT revealed lymph-node metastasis in ten cases (22.7\%); the remaining 34 cases $(77.3 \%)$ showed no lymph-node swelling. Two cases (4.5\%) showed distant metastasis.

ISH. Five of the 44 cases (11.4\%) showed the expression of HR HPV. None of the patients showed the expression of LR HPV (Table I). We next examined the correlation between the expression of HR HPV and age, tumor location, tumor size, $\mathrm{T}$ stage, pathological differentiation, nuclear grade, Broder's classification, pattern of invasion, Y-K grade, vascular invasion, lymphoid invasion, koilocytosis, and lymph-node metastasis. Patients with a well-differentiated status $(\mathrm{P}=0.044)$ and Broder's Grade $1(\mathrm{P}=0.019)$ showed a significantly lower rate 
Table II. Previous studies of HPV expression in solid malignancies.

\begin{tabular}{|c|c|c|c|c|c|}
\hline Author, year & Organ & No. of patients & Detection methods & HPV detectable rate $(\%)$ & (Refs.) \\
\hline Gillison et al, 2000 & Head and neck & 253 & PCR, ISH & 25 & $(18)$ \\
\hline Li et al, 2003 & Tonsil & 86 & PCR & 46 & (19) \\
\hline Ritchie et al, 2003 & Oropharynx & 139 & PCR & 21 & (20) \\
\hline Ansink et al,1994 & Vulva & 60 & PCR & 32 & $(21)$ \\
\hline Bosch et al,1997 & Cervix & 1,035 & PCR & 93 & $(22)$ \\
\hline ter Harmsel et al, 1999 & Cervix & 159 & PCR & 100 & $(23)$ \\
\hline Wiener et al, 1992 & Penis & 29 & PCR & 31 & $(24)$ \\
\hline Bezerra et al, 2001 & Penis & 82 & PCR & 30.50 & $(17)$ \\
\hline Lont et al, 2006 & Penis & 171 & PCR & 29 & $(16)$ \\
\hline Senba et al, 2006 & Penis & 65 & PCR, ISH & ISH 53.8, PCR 81.5 & $(25)$ \\
\hline
\end{tabular}

PCR, polymerase chain reaction; ISH, in situ hybrisation; HPV, human papillomavirus.

of HPV positivity. The HPV expression was not significantly associated with the cancer-specific survival ( $\mathrm{P}=0.932$; Fig. 4).

\section{Discussion}

HPV is reportedly detectable by ISH in 30-80\% of cervical cancer cases. The rate of HPV positivity in the present study (11.4\%) was low in comparison to previous reports (14). Some possible reasons for this are as follows: i) Japanese penile cancer patients show a lower rate of HPV positivity; ii) an HPV genotype that is not detectable by this kit might play a role in penile cancer; or iii) the HPV gene volume might be lower in comparison to cervical cancer.

Histologically, the expression of HPV is thought to be positively associated with tumor differentiation and keratinocytosis. However, a negative association has been reported between the HPV expression and tumor differentiation (15). The present study revealed that poorly differentiated cancer was associated with a higher rate of HPV positivity. Previous studies of patients with solid cancers have also reported that patients with poorly differentiated tumors showed a higher rate of HPV positivity. HPV expressions in reported organs were varied by organ (Table II) (16-25).

In cervical cancer, HPV plays an important role in cancer development and HPV vaccination is widely performed. According to a previous report more than $90 \%$ of cervical cancer patients are positive for HPV-DNA (26). Some reports have shown that HPV vaccination might prevent squamous cell carcinoma in the anus, skin, and neck $(26,27)$. On the other hand, in cancers other than cervical cancer, the rate of HPV positivity varies by country and age and there is no apparent correlation between cancer development and HPV infection $(28,29)$. The female sexual partners of patients with penile cancer do not have an increased incidence of cervical cancer. At present, there is no recommendation for the use of HPV vaccination in boys due to the differences in the HPV-associated risk patterns in relation to penile and anal cancer. Furthermore, the epidemiological effects of HPV vaccination and its acceptance in girls will have to be assessed before any further recommendations can be made $(30,31)$.

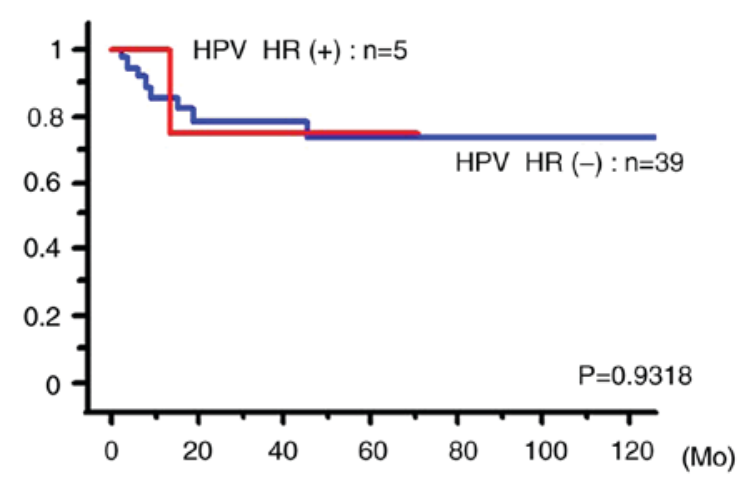

Figure 4. Kaplan-Meier curve between the HPV-positive and HPV-negative groups. There were no significant differences in cancer specific survival in terms of HPV positive or not. HPV, human papillomavirus; HR, high-risk.

It is not clear whether the prognosis of HPV-associated penile cancer differs from that of non-HPV-associated penile cancer. The 5-year disease-specific survival of patients with HPV-positive penile cancer was reported to be significantly better than that of HPV-negative penile cancer (93\% vs. 78\%) in one study (16), while another study reported that there was no difference in the rates of lymph node metastasis or 10-year survival (17).

The details of the correlation between the expression of HPV and the prognosis remain unknown. Sonpavde et al reported that HPV-expression-positive penile cancer was associated with a favorable outcome (32). The present study showed no significant association between the rate of HPV expression and the outcome; however, the study population was relatively small.

There were no significant differences in the rate of koilocytosis. This means that koilocytosis might have been the result of an active HR HPV infection or the presence of koilocytosis might indicate a previous HPV infection.

In conclusion, HR HPV was detected in 5 of $44(11.4 \%)$ penile cancer cases. LR HPV was not detected in any of the cases. There was some correlation between the expression of HR HPV and the tumor differentiation and keratinization (Border's classification). The OS of the HPV-positive patients 
did not differ from that of the HPV-negative patients. Although ISH using INFORM HPVIII does not detect the HPV genotype, this method is easy to use and might be useful for examining penile cancer tissue, as it is for cervical cancer tissue.

\section{Acknowledgements}

Grants from KAKENHI grants (16K20152) from the Ministry of Education, Culture, Sports, Science and Technology of Japan and grant for 2016-2017 Research Development Fund (nos. WJ2810) of Yokohama City University.

\section{References}

1. Lu B, Wu Y, Nielson CM, Flores R, Abrahamsen M, Papenfuss M, Harris RB and Giuliano AR: Factors associated with acquisition and clearance of human papillomavirus infection in a cohort of US men: A prospective study. J Infect Dis 199: 362-371, 2009.

2. da Costa WH, Rosa de Oliveira RA, Santana TB, Benigno BS, da Cunha IW, de Cássio Zequi S, Guimaraes GC and Lopes A Prognostic factors in patients with penile carcinoma and inguinal lymph node metastasis. Int J Urol 22: 669-673, 2015.

3. Bleeker MC, Heideman DA, Snijders PJ, Horenblas S, Dillner J and Meijer CJ: Penile cancer: Epidemiology, pathogenesis and prevention. World J Urol 27: 141-150, 2009.

4. Iwasawa A, Kumamoto Y and Fujinaga K: Detection of human papillomavirus deoxyribonucleic acid in penile carcinoma by polymerase chain reaction and in situ hybridization. J Urol 149: 59-63, 1993.

5. Giuliano AR, Nielson CM, Flores R, Dunne EF, Abrahamsen M, Papenfuss MR, Markowitz LE, Smith D and Harris RB: The optimal anatomic sites for sampling heterosexual men for human papillomavirus (HPV) detection: The HPV detection in men study. J Infect Dis 196: 1146-1152, 2007.

6. Nielson CM,Flores R, Harris RB, Abrahamsen M,Papenfuss MR, Dunne EF, Markowitz LE and Giuliano AR: Human papillomavirus prevalence and type distribution in male anogenital sites and semen. Cancer Epidemiol Biomarkers Prev 16: 1107-1114, 2007.

7. Rombaldi RL, Serafini EP, Villa LL, Vanni AC, Baréa F, Frassini R, Xavier M and Paesi S: Infection with human papillomaviruses of sexual partners of women having cervical intraepithelial neoplasia. Braz J Med Biol Res 39: 177-187, 2006.

8. Cohen C, Lawson D, Jiang J and Siddiqui MT: Automated in situ hybridization for human papilloma virus. Appl Immunohistochem Mol Morphol 22: 619-622, 2014

9. Lodde M, Mian C, Mayr R, Comploj E, Trenti E, Melotti R, Campodonico F, Maffezzini M, Fritsche HM and Pycha A: Recurrence and progression in patients with non-muscle invasive bladder cancer: Prognostic models including multicolor fluorescence in situ hybridization molecular grading. Int J Urol 21 968-972, 2014

10. Hopman AH, Kamps MA, Smedts F, Speel EJ, Herrington CS and Ramaekers FC: HPV in situ hybridization: Impact of different protocols on the detection of integrated HPV. Int J Cancer 115: 419-428, 2005.

11. Pirog EC: Immunohistochemistry and in situ hybridization for the diagnosis and classification of squamous lesions of the anogenital region. Semin Diagn Pathol 32: 409-418, 2015.

12. Ishida M, Ohashi S, Kizaki Y, Naito J, Horiguchi K and Harigaya T: Expression profiling of mouse placental lactogen II and its correlative genes using a cDNA microarray analysis in the developmental mouse placenta. J Reprod Dev 53: 69-76, 2007.

13. Stratton KL and Culkin DJ: A contemporary review of HPV and penile cancer. Oncology (Williston Park) 30: 245-249, 2016.

14. Weaver MG, Abdul-Karim FW, Dale G, Sorensen K and Huang YT: Detection and localization of human papillomavirus in penile condylomas and squamous cell carcinomas using in situ hybridization with biotinylated DNA viral probes. Mod Pathol 2 94-100, 1989

15. Klussmann JP, Weissenborn SJ, Wieland U, Dries V, Eckel HE, Pfister HJ and Fuchs PG: Human papillomavirus-positive tonsillar carcinomas: A different tumor entity? Med Microbiol Immunol 192: 129-132, 2003.
16. Lont AP, Kroon BK, Horenblas S, Gallee MP, Berkhof J, Meijer CJ and Snijders PJ: Presence of high-risk human papillomavirus DNA in penile carcinoma predicts favorable outcome in survival. Int J Cancer 119: 1078-1081, 2006.

17. Bezerra AL, Lopes A, Santiago GH, Ribeiro KC, Latorre MR and Villa LL: Human papillomavirus as a prognostic factor in carcinoma of the penis: Analysis of 82 patients treated with amputation and bilateral lymphadenectomy. Cancer 91: 2315-2321, 2001

18. Gillison ML, Koch WM, Capone RB, Spafford M, Westra WH, Wu L, Zahurak ML, Daniel RW, Viglione M, Symer DE, et al: Evidence for a causal association between human papillomavirus and a subset of head and neck cancers. J Natl Cancer Inst 92: 709-720, 2000

19. Li W, Thompson CH, Xin D, Cossart YE, O'Brien CJ, McNeil EB, Gao K, Scolyer RA and Rose BR: Absence of human papillomavirus in tonsillar squamous cell carcinomas from Chinese patients. Am J Pathol 163: 2185-2189, 2003.

20. Ritchie JM, Smith EM, Summersgill KF, Hoffman HT, Wang D, Klussmann JP, Turek LP and Haugen TH: Human papillomavirus infection as a prognostic factor in carcinomas of the oral cavity and oropharynx. Int J Cancer 104: 336-344, 2003.

21. Ansink AC, Krul MR, De Weger RA, Kleyne JA, Pijpers H, Van Tinteren H, De Kraker EW, Helmerhorst TJ and Heintz AP: Human papillomavirus, lichen sclerosus, and squamous cell carcinoma of the vulva: Detection and prognostic significance. Gynecol Oncol 52: 180-184, 1994.

22. Bosch FX, Muñoz N and de Sanjosé S: Human papillomavirus and other risk factors for cervical cancer. Biomed Pharmacother 51: 268-275, 1997.

23. ter Harmsel B, Smedts F, Kuijpers J, van Muyden R, Oosterhuis W and Quint W: Relationship between human papillomavirus type 16 in the cervix and intraepithelial neoplasia. Obstet Gynecol 93: 46-50, 1999.

24. Wiener JS, Effert PJ, Humphrey PA, Yu L, Liu ET and Walther PJ: Prevalence of human papillomavirus types 16 and 18 in squamous-cell carcinoma of the penis: A retrospective analysis of primary and metastatic lesions by differential polymerase chain reaction. Int J Cancer 50: 694-701, 1992.

25. Senba M, Kumatori A, Fujita S, Jutavijittum P, Yousukh A, Moriuchi T, Nakamura T and Toriyama K: The prevalence of human papillomavirus genotypes in penile cancers from northern Thailand. J Med Virol 78: 1341-1346, 2006.

26. Muñoz N, Bosch FX, de Sanjosé S, Herrero R, Castellsagué X, Shah KV, Snijders PJ and Meijer CJ; International Agency for Research on Cancer Multicenter Cervical Cancer Study Group: Epidemiologic classification of human papillomavirus types associated with cervical cancer. N Engl J Med 348: 518-527, 2003.

27. Furihata $\mathrm{M}$, Inoue $\mathrm{K}$, Ohtsuki $\mathrm{Y}$, Hashimoto $\mathrm{H}$, Terao $\mathrm{N}$ and Fujita Y: High-risk human papillomavirus infections and overexpression of $\mathrm{p} 53$ protein as prognostic indicators in transitional cell carcinoma of the urinary bladder. Cancer Res 53: 4823-4827, 1993.

28. Philippou P, Shabbir M, Ralph DJ, Malone P, Nigam R, Freeman A, Muneer A and Minhas S: Genital lichen sclerosus/balanitis xerotica obliterans in men with penile carcinoma: A critical analysis. BJU Int 111: 970-976, 2013.

29. D'Hauwers KW, Depuydt CE, Bogers JJ, Noel JC, Delvenne P, Marbaix E, Donders AR and Tjalma WA: Human papillomavirus, lichen sclerosus and penile cancer: A study in Belgium. Vaccine 30: 6573-6577, 2012.

30. Newman PA, Logie CH, Doukas N and Asakura K: HPV vaccine acceptability among men: A systematic review and meta-analysis. Sex Transm Infect 89: 568-574, 2013.

31. Fisher H, Trotter CL, Audrey S, MacDonald-Wallis K and Hickman M: Inequalities in the uptake of human papillomavirus vaccination: A systematic review and meta-analysis. Int $\mathrm{J}$ Epidemiol 42: 896-908, 2013.

32. Sonpavde G, Pagliaro LC, Buonerba C, Dorff TB, Lee RJ and Di Lorenzo G: Penile cancer: Current therapy and future directions. Ann Oncol 24: 1179-1189, 2013. 